\title{
Kinetics of the urea-urease clock reaction with urease immobilized in hydrogel beads
}

\author{
Itana Nuša Bubanja ${ }^{1}$ Tamás Bánsági Jr. ${ }^{2} \cdot{\text { Annette Fiona } \text { Taylor }^{2} \text { (D }}$
}

Received: 3 September 2017/ Accepted: 21 October 2017/Published online: 31 October 2017

(C) The Author(s) 2017. This article is an open access publication

\begin{abstract}
Feedback driven by enzyme catalyzed reactions occurs widely in biology and has been well characterized in single celled organisms such as yeast. There are still few examples of robust enzyme oscillators in vitro that might be used to study nonlinear dynamical behavior. One of the simplest is the urea-urease reaction that displays autocatalysis driven by the increase in $\mathrm{pH}$ accompanying the production of ammonia. A clock reaction was obtained from low to high $\mathrm{pH}$ in batch reactor and bistability and oscillations were reported in a continuous flow rector. However, the oscillations were found to be irreproducible and one contributing factor may be the lack of stability of the enzyme in solution at room temperature. Here, we investigated the effect of immobilizing urease in thiol-poly(ethylene glycol) acrylate (PEGDA) hydrogel beads, prepared using emulsion polymerization, on the ureaurease reaction. The resultant $\mathrm{mm}$-sized beads were found to reproduce the $\mathrm{pH}$ clock and, under the conditions employed here, the stability of the enzyme was increased from hours to days.
\end{abstract}

Keywords Feedback · Urease · Clock reaction · Immobilized enzyme particles

This paper is dedicated to Professor Ljiljana Kolar-Anic on the occasion of her 70th birthday.

Annette Fiona Taylor

a.f.taylor@sheffield.ac.uk

1 Faculty of Physical Chemistry, University of Belgrade, Belgrade, Serbia

2 Department of Chemical and Biological Engineering, University of Sheffield, Sheffield, UK 


\section{Introduction}

Feedback driven by enzymes occurs naturally in living systems and is responsible for behaviours such as signal amplification, a switch in response to a signal e.g. cell maturation or apoptosis, and rhythms during glycolysis in yeast cells [1]. Biological processes typically involve a complex network of enzyme catalyzed reactions, for example, glycolysis is a sequence of 10 enzyme catalysed reactions. The oscillations in yeast are generally thought to arise as a result of the allosteric effects of the enzyme PFK during the step involving phosphorylation of fructose- 6 phosphate and transformation of ATP to ADP. The catalyst PFK is activated by the product ADP, thus positive feedback ensues. Oscillations and waves have been obtained in suspensions of yeast cells in closed and open flow reactors, and in cell extracts, but to date no oscillations have been reported in systems with the PFK enzyme alone $[2,3]$.

Another example of a biochemical oscillator that can display complex behavior in vitro is the peroxidase-oxidase reaction [4]. In this system, the peroxidase enzyme catalyzes oxidization of a substrate e.g. NADH by oxygen. Oscillations have been observed in a semi-batch reactor in which NADH and air is added to a solution containing enzyme and co-factors dichlorophenol and methylene blue. Although the reaction requires a single enzyme, the mechanism involves many radical reactions and multiple enzyme states with different oxidation states at the heme group active site. The hydrogenase enzyme catalyzed reaction also displays autocatalysis and propagating waves but the mechanism of this reaction is still under investigation [5].

An alternative strategy for obtaining oscillations in a reaction involving a single enzyme was proposed in 1973 [6] and exploits feedback through the bell-shaped rate-pH curve of enzymes [7] coupled with acid or base production. Oscillations were obtained in a computer simulation involving an enzyme, papain, immobilized in a membrane that catalyzed hydrolysis of an ester producing a carboxylic acid. The acid produced accelerates the rate of reaction effectively catalyzing its own production. Later analysis suggested that the higher diffusion rate of acid in solution, compared to that of other species, is essential and that oscillations will only be observed for a relatively narrow range of parameters [8-10].

This mechanism for the design of an enzyme oscillator has been explored further in two systems with enzymes glucose oxidase [11] and urease [12]. The ureasecatalyzed hydrolysis of urea yields ammonia and carbon dioxide (reaction 1), and the ammonia causes an increase in the $\mathrm{pH}$ (reaction $2, \mathrm{pK}_{\mathrm{a}}=9.34$ ):

$$
\begin{gathered}
\mathrm{CO}\left(\mathrm{NH}_{2}\right)_{2}+\mathrm{H}_{2} \mathrm{O} \stackrel{\text { urease }}{\longrightarrow} 2 \mathrm{NH}_{3}+\mathrm{CO}_{2} \quad v_{0}=\frac{V_{\max } U}{\left(K_{M}+U\right)\left(1+\frac{K_{\mathrm{es} 2}}{\left[H^{+}\right]}+\frac{\left[H^{+}\right]}{K_{\mathrm{es} 1}}\right)} \\
\mathrm{NH}_{3}+\mathrm{H}^{+} \leftrightarrow \mathrm{NH}_{4}^{+}
\end{gathered}
$$

The mechanism of the urease reaction has been extensively investigated [13] and, in its simplest form, the enzyme rate can be expressed as a modified MichaelisMenten expression (shown in Eq. 1) where $v_{0}$ is the enzyme rate, $U$ is the urea concentration, $V_{\max }$ is the maximum rate and $K_{\mathrm{M}}$ is the Michaelis constant. The 
expression includes the dependence of the enzyme activity on acid concentration: $K_{\text {es2 }}$ and $K_{\text {es1 }}$ are binding coefficients of the enzyme to acid. Urease is a ubiquitous enzyme found in numerous plants and micro-organisms. It is most often extracted from Jack bean and has a maximum rate at $\mathrm{pH}$ 7.4. If this enzyme is added to a solution of acid and urea, then as ammonia is produced, a rapid switch from acid to base occurs after a controllable period of time [12].

Propagating $\mathrm{pH}$ fronts have been obtained in thin layers of solution in the ureaurease reaction and bistability and oscillations were observed in an open flow reactor under certain conditions [10]. However, experimental observations of oscillations under non-buffered conditions with urease are difficult to reproduce. One of the reasons for this may be the lack of stability of the enzyme in stock solutions at room temperature. In order to create a robust oscillator, this loss of enzyme activity must be overcome.

Increased urease stability has been obtained by immobilization of the enzyme on numerous solid supports [14]. One of the potential drawbacks of immobilization is that although it increases longevity, there is typically also a decrease in the activity of the enzyme. This can arise from changes in the conformational state of the enzyme that affect the active site, or diffusional issues which prevent transport of the substrate to the active site. In order to circumvent the latter, hydrogels with more open structures may be used. Here we investigated the employment of a novel thiolacrylate hydrogel [15] for immobilization of the enzyme urease. The mm-sized hydrogel beads were prepared using emulsion polymerization and the catalytic activity and stability of the urease beads was compared to solution phase experiments.

\section{Experimental methods}

\section{Urea-urease clock reaction}

Urea (Fisher), urease (type III from Jack Bean, 34,310 U/g, Sigma) and hydrochloric acid (1 M, Fluka) were all used as purchased. Stock solutions of urea $(0.2 \mathrm{M})$ and urease $(50 \mathrm{units} / \mathrm{ml})$ were prepared using distilled deionized water (Millipore 18.2 O).

For the urea-urease clock reactions, different volumes of enzyme stock solution were added into a solution of urea and hydrochloric acid to give $16 \mathrm{ml}$ total volume. For example, $250 \mu \mathrm{l}$ urea and $2 \mu \mathrm{HCl}$ were added to $15.65 \mathrm{ml}$ of water then $100 \mu \mathrm{l}$ of urease solution was added to initiate the reaction. Enzyme activity (in U/ml;

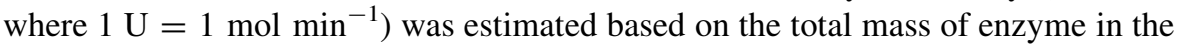
total volume of solution. The clock reaction was performed under well stirred batch reactor conditions using a magnetic stirrer bar and the $\mathrm{pH}$ of the bulk solution was recorded by Schott $\mathrm{pH}$ electrode and PicoLog Software.

All experiments were performed at room temperature $\left(20 \pm 1{ }^{\circ} \mathrm{C}\right)$. The enzyme stock solution was kept at room temperature and the age of the solution was recorded for investigations of the effect of enzyme degradation on the clock reaction. 


\section{Thiol-acrylate hydrogel beads}

Poly(ethylene glycol) diacrylate (PEGDA, average $M_{n}=700$ ) was purchased from Sigma Aldrich. The tri-thiol: ethoxylated trimethylolpropane tri(3-mercaptopropionate) (THIOCURE ${ }^{\circledR}$ ETTMP 1300) was acquired from Bruno Bock Chemicals. Poly vinyl alcohol (PVA, $\mathrm{M}_{\mathrm{w}} \sim 61000$ ) and hexane were also purchased from Sigma. All chemicals were used as received and a stock solution of of PVA was prepared $(5 \mathrm{~g}$ in $50 \mathrm{ml}$ distilled deionized water).

The thiol-acrylate hydrogel was originally proposed as a base-catalyzed polymerization for injectable drug formulations [15] and this recipe was subsequently modified to obtain gelation after a programmable time lag using the increase in $\mathrm{pH}$ of the urea-urease reaction [9]. Here we further modified the formulation with the addition of PVA in order to obtain gel beads using emulsion polymerisation. When the reaction $\mathrm{pH}$ increases, the beads are formed.

A stock solution was prepared with (a) $0.02 \mathrm{~g}$ urease $(34,310 \mathrm{U} / \mathrm{g}$ ) (b) $2000 \mu \mathrm{l}$ PVA $(0.1 \mathrm{~g} / \mathrm{ml}$ ) (c) $1150 \mu \mathrm{l}$ THIOCURE (d) $900 \mu \mathrm{l}$ PEGDA (e) $2200 \mu \mathrm{l}$ urea $(0.05 \mathrm{M})$. The total volume of the solution was $6.25 \mathrm{ml}$. Before gelation could occur, $1.6 \mathrm{ml}$ was taken and injected drop-wise into $48.5 \mathrm{ml}$ hexane. The solution was stirred using a magnetic stirrer at $600 \mathrm{rpm}$ until beads were formed. The beads were then separated from hexane and washed several times with distilled water. The maximum amount of enzyme present per gram of beads was calculated (as enzyme mass $0.02 \mathrm{~g} / \mathrm{mass}$ of solution $6.25 \mathrm{~g}$, assuming no loss during the process) as $3.2 \times 10^{-3} \mathrm{~g} / \mathrm{g}$ or $110 \mathrm{U} / \mathrm{g}$ bead.

The same experimental procedure for the urea-urease reaction in a batch reactor was performed but now with a fixed mass of urease-loaded hydrogel beads in place of urease solutions. Different amounts of beads were added to $100 \mathrm{ml}$ of acidic urea solution. The enzyme activity was estimated (for comparison with the solution phase experiments) from the maximum amount of enzyme in the beads/volume of solution. The urease polymer beads were kept in water at room temperature and the age of the beads was recorded.

\section{Results}

Typical $\mathrm{pH}$ profiles in the urea-urease reaction are shown in Fig. 1a for different concentrations of urease but the same concentrations of urea and hydrochloric acid. There is an initial slow increase in $\mathrm{pH}$ followed by a more rapid increase up to $\mathrm{pH} 7$. The $\mathrm{pH}$ then increases less rapidly up to $\mathrm{pH} 9$.

The clock time was defined here as the time taken for the rate of change of $\mathrm{pH}$ to reach a maximum (approx. to $\mathrm{pH}$ 7). The clock time increased with decreasing concentration of enzyme and for these experimental conditions, showed an exponential-like dependence on the initial concentration of urease (Fig. 1b).

The effect of the age of the enzyme stock solution on the clock reaction is shown in Fig. 2a for the same initial concentrations of urea and acid and an initial enzyme concentration of $0.309 \mathrm{U} / \mathrm{ml}$ (before aging took place). Increasing the age of the stock solution had a similar effect to decreasing the concentration of enzyme. 
(a)

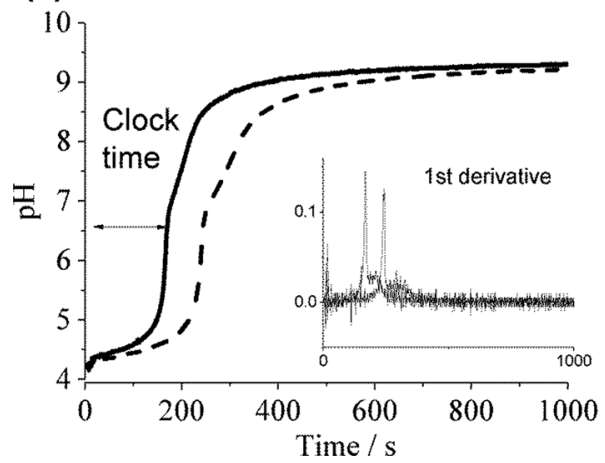

(b)

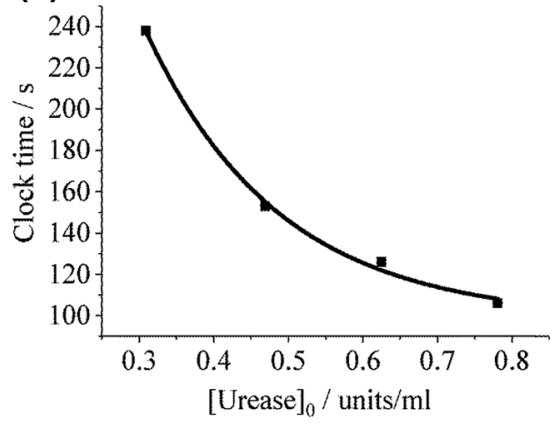

Fig. 1 a pH-time curves obtained for urea-urease reaction in a batch reactor for following conditions: $[\text { urea }]_{0}=3.09 \mathrm{mM},[\mathrm{HCl}]_{0}=0.125 \mathrm{mM}$, [urease $]_{0}=0.469$ units $/ \mathrm{ml}$ (solid), [urease $]_{0}=0.309$ units $/ \mathrm{ml}$ (dash). Inset shows first derivative used to calculate clock time and $\mathbf{b}$ a plot of clock time vs initial concentration of urease (curve shows exponential fit to data $y=A e^{-k x}+B$ with $A=786, k=5.6$ and $B=98)$ )

(a)

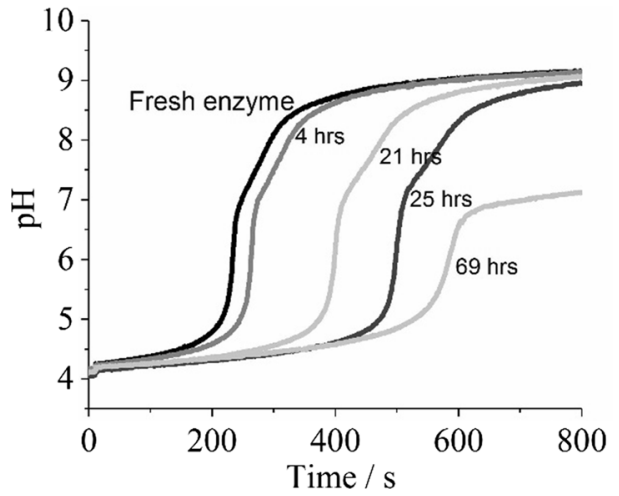

(b)

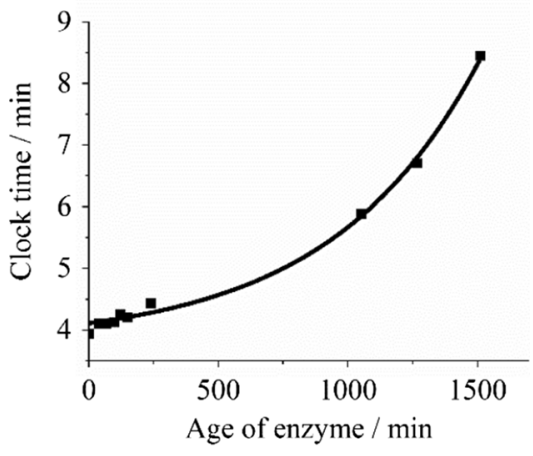

Fig. 2 a pH curves obtained for different ages of enzyme stock solution and $\mathbf{b}$ a plot of age of enzyme stock solution versus clock time (curve shows exponential fit to data $y=A e^{k x}+B$ with $A=0.33$, $k=0.0175$ and $B=3.8$ ). Initial conditions were: [urea $]_{0}=3.09 \mathrm{mM},[\mathrm{HCl}]_{0}=0.125 \mathrm{mM}$ and [urease $]_{0}=0.309 \mathrm{U} / \mathrm{ml}($ at age $=0 \mathrm{~h})$

Finally, when the age of the enzyme solution was $69 \mathrm{~h}$ the $\mathrm{pH}$ failed to reach basic values. In Fig. $2 b$ a plot of clock time versus age of enzyme is shown. For these conditions, after 2 days kept at room temperature in water, the enzyme lost its activity such that the $\mathrm{pH}$ clock was no longer obtained.

In order to slow down process of enzyme degradation, urease-immobilized hydrogel beads were prepared using emulsion polymerization (see Experimental section). The bead sizes ranged between 0.5 and $3 \mathrm{~mm}$ (Fig. 3).

After washing, the beads were added to solutions of urea and acid and the $\mathrm{pH}$ change in time was recorded. In Fig. 4a, three $\mathrm{pH}$ curves obtained for different amounts of urease-immobilized hydrogel beads are shown. The activity was 
Fig. 3 Thiol-acrylate hydrogel beads containing urease enzyme on mm-square paper

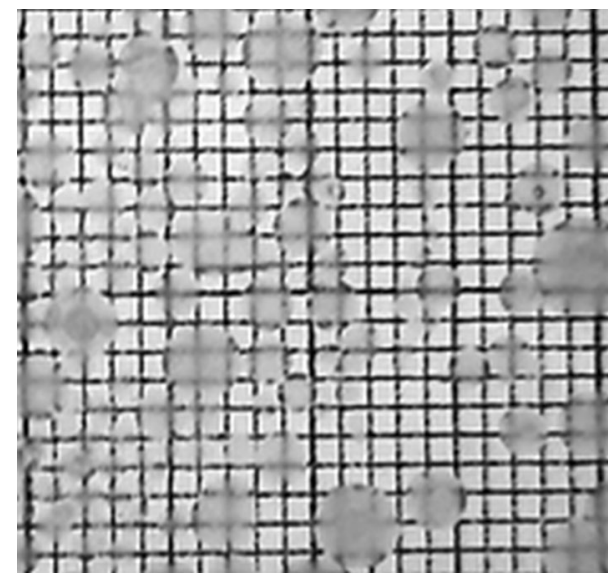

(a)

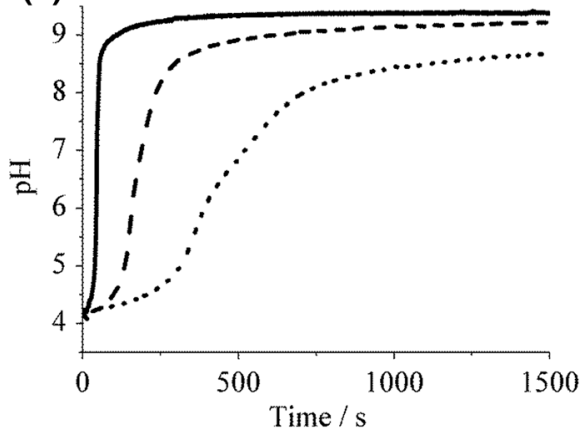

(b)

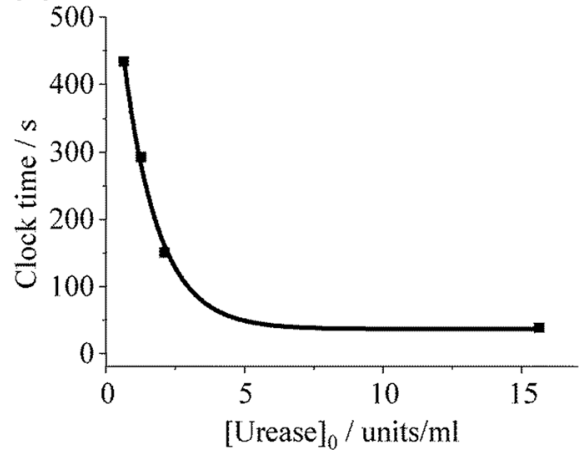

Fig. 4 a pH curves obtained for urea-urease reaction in batch reactor with different amounts of polymer beads added for initial conditions: [urea $]_{0}=3.09 \mathrm{mM}$ and $[\mathrm{HCl}]_{0}=0.125 \mathrm{mM}$, and the calculated activity of urease was: [urease $]_{0}=15.6 \mathrm{U} / \mathrm{ml}$ (solid), [urease $]_{0}=2.11 \mathrm{U} / \mathrm{ml}$ (dash), $[\text { urease }]_{0}=0.632$ units $/ \mathrm{ml}$ (dot). b A plot of clock time vs calculated activity of enzyme (curve shows fitted exponential decay: $y=A e^{-k x}+B$ with $A=662, k=0.79$ and $B=37$ )

calculated based on the maximum amount of enzyme possible from the immobilization process. Comparison of the dotted curve with activity of $0.632 \mathrm{U} / \mathrm{ml}$ with the curve in Fig. 1a for enzyme $0.469 \mathrm{U} / \mathrm{ml}$ indicates that either enzyme has been lost during the process, or the activity is reduced in the hydrogel beads as a result of mass transport effects. The rate of change of $\mathrm{pH}$ and the maximum $\mathrm{pH}$ is lower than expected. However, increasing the amount of beads recovers the $\mathrm{pH}$ clock. A plot of clock time versus calculated activity of urease is shown in Fig. 4b. This has the same form as in Fig. 2 for the solution phase experiment.

The stability of the urease in the hydrogel beads compared to that in solution was also determined from clock reaction experiments. The $\mathrm{pH}$-time curve of the reaction was found to be unaffected with beads up to two days old (Fig. 5a). After 7 days, the rate of increase of $\mathrm{pH}$ was reduced and the clock time increased. However, a high $\mathrm{pH}$ was still obtained. The activity was completely lost after 9 days. The 
(a)

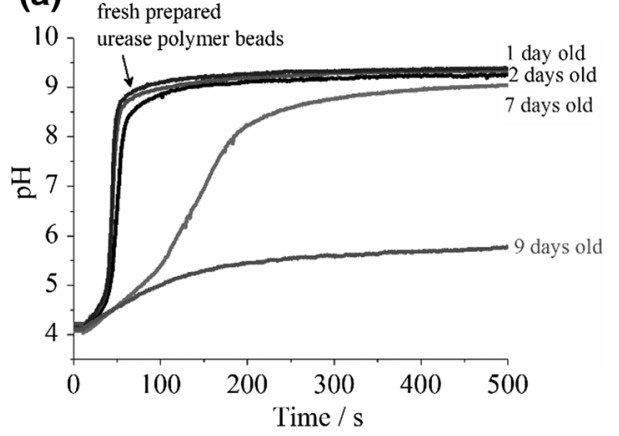

(b)

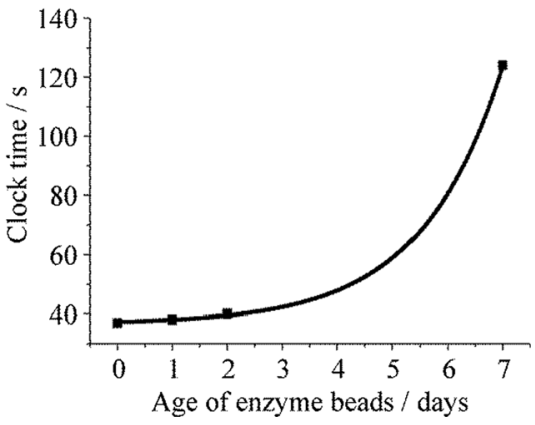

Fig. 5 a pH-time curves obtained for different ages of enzyme in hydrogel beads [urea $]_{0}=3.09 \mathrm{mM}$ and $[\mathrm{HCl}]_{0}=0.125 \mathrm{mM}$ and [urease $]_{0}=15.6 \mathrm{U} / \mathrm{ml}$ and $\mathbf{b}$ a plot of clock time vs age of enzyme in beads (curve shows exponential fit $\left(y=A e^{k x}+B\right.$ with $A=0.33, k=0.0175$ and $\left.B=3.8\right)$. Conditions are the same is in Fig. 4

increase of clock time obtained with increasing age of the beads is shown in Fig. $5 \mathrm{~b}$. An increase in stability was therefore obtained, compared to the free enzyme in solution.

\section{Discussion and conclusions}

The urea-urease reaction is possibly the simplest example of an enzyme catalyzed reaction displaying nonlinear dynamical behavior. The mechanism of the reaction involves a Michaelis-Menten expression modified to take into account the bellshaped rate dependence on $\mathrm{pH}$ with a maximum at $\mathrm{pH} 7.4$ [13].

In a batch reactor, the reaction produces ammonia which raises the $\mathrm{pH}$ and a characteristic $\mathrm{pH}$ "clock" is obtained in which the $\mathrm{pH}$ switches from a low to high value [12]. It is important to note, however, that feedback is not required for such a profile to occur in an acid-base reaction. The $\mathrm{pH}$ change is initially slow because of the base produced is neutralized by acid. This scenario is similar to clock reactions involving consumption of inhibitor rather than autocatalysis [16]. However, in the urea-urease reaction, rate acceleration is also observed in the rate of consumption of the reactant, urea. The feedback that arises with increasing $\mathrm{pH}$ is required for propagating fronts and bistablity, or oscillations, observed in the flow reactor. However, oscillations were found to be irreproducible and the loss of activity of enzyme in the stock solutions at room temperature may be a contributing factor.

Urease has been immobilized on a vast number of solid supports using chemical or physical techniques in order to improve its longevity [14]. With surface modifications, urease has been covalently attached to silk, gelatin, nylon and polystyrene beads among others. The enzyme has been adsorbed on porous silica, hydroxyapatite, alumina particles and encapsulated in alginate, chitosan and cellulose. In all these cases, the stability of the enzyme was greatly improved. For example, with gelatin, the half-life of the enzyme (defined as the time taken for the 
enzyme activity to fall to half of its original value) stored at $4{ }^{\circ} \mathrm{C}$ was 20 days for the free enzyme and 90 days for the immobilized enzyme [14]. However, the enzyme activity was reduced compared to the free enzyme and the $\mathrm{pH}$ optimum and Michaelis constant also changed. With gelatin, the activity was reduced to $68 \%$ of the original activity and the $\mathrm{pH}$ optimum increased to $\mathrm{pH}$ 8. These effects mean that the rate acceleration observed under non-buffered conditions may no longer be obtained.

Here we investigated the use of a novel thiol-acrylate polymer using emulsion polymerization to form urease-loaded mm-sized beads. This polymer was proposed for use in injectable drug formulations [15]. We were interested in the performance of the enzyme under non-buffered conditions at room temperature. Direct comparison with most other immobilization techniques is not possible since the storage and reaction conditions (i.e. temperature, buffer as well as source and amount of enzyme) were different. However, we can compare with earlier studies of the clock reaction performed with the enzyme immobilized in alginate beads. In this case although the beads displayed initially high activity, this was found to decrease over the over the course of hours [17]. Using a fixed mass of thiol-acrylate beads in a solution of urea and acid we found that the enzyme-loaded beads were able to produce $\mathrm{pH}$ clock reactions similar to those obtained in the solution phase experiments. We also found that the loss of the enzyme activity was reduced, compared to the solution phase experiments, such that activity was unaffected over several days compared to hours with the enzyme free in water. Thus it is possible to explore feedback-driven behavior with these beads.

Many unicellular organisms such as yeast display complex nonlinear behavior driven by enzyme catalyzed reactions. The immobilization of enzymes in particles may provide insight into some of their observed behaviors. There is also increasing interest in coupling $\mathrm{pH}$ oscillators with $\mathrm{pH}$ sensitive materials for applications [18]. The dynamics predicted in simulations of urease-loaded particles, including oscillations, are yet to be obtained and the stability of the enzyme must be increased for such studies. Thus the thiol-acrylate polymer is a promising medium for further investigations of nonlinear effects with this simple enzyme-catalyzed reaction.

Acknowledgements INB thanks COST action CM1304 Emergence and Evolution in Complex Chemical Systems for funding a Short Term Scientific Mission to the University of Sheffield and AFT and TB thank EPSRC EP/K030574/2 for financial support.

Open Access This article is distributed under the terms of the Creative Commons Attribution 4.0 International License (http://creativecommons.org/licenses/by/4.0/), which permits unrestricted use, distribution, and reproduction in any medium, provided you give appropriate credit to the original author(s) and the source, provide a link to the Creative Commons license, and indicate if changes were made. 


\section{References}

1. Goldbeter A, Caplan SR (1976) Oscillatory enzymes. Annu Rev Biophys Bioeng 5:449-476

2. Bagyan S, Mair T, Dulos E, Boissonade J, De Kepper P, Muller SC (2005) Glycolytic oscillations and waves in an open spatial reactor: impact of feedback regulation of phosphofructokinase. Biophys Chem 116(1):67-76

3. Schutze J, Mair T, Hauser MJB, Falcke M, Wolf J (2010) Metabolic synchronization by traveling waves in yeast cell layers. Biophys J 100(4):809-813

4. Bakes D, Schreiberova L, Schreiber I, Hauser MJB (2008) Mixed-mode oscillations in a homogeneous pH-oscillatory chemical reaction system. Chaos 18(1):12

5. Bodo G, Branca RMM, Toth A, Horvath D, Bagyinka C (2009) Concentration-dependent front velocity of the autocatalytic hydrogenase reaction. Biophys J 96(12):4976-4983

6. Caplan SR, Naparste A, Zabusky NJ (1973) Chemical oscillations in a membrane. Nature 245(5425):364-366

7. Chang R (2005) Enzyme kinetics. In: Physical chemistry for the biosciences. University Science Books

8. Bánsági T, Taylor AF (2014) Role of differential transport in an oscillatory enzyme reaction. J Phys Chem B 118(23):6092-6097

9. Jee E, Bánsági T Jr, Taylor AF, Pojman JA (2016) Temporal control of gelation and polymerization fronts driven by an autocatalytic enzyme reaction. Angew Chem 55(6):2127-2131

10. Wrobel MM, Bánsági T Jr, Scott SK, Taylor AF, Bounds CO, Carranzo A, Pojman JA (2012) PH wave-front propagation in the urea-urease reaction. Biophys J 103(3):610-615

11. Miguez DG, Vanag VK, Epstein IR (2007) Fronts and pulses in an enzymatic reaction catalyzed by glucose oxidase. Proc Natl Acad Sci USA 104(17):6992-6997

12. Hu G, Pojman JA, Scott SK, Wrobel MM, Taylor AF (2010) Base-catalyzed feedback in the ureaurease reaction. J Phys Chem B 114(44):14059-14063

13. Krajewska B (2009) Ureases I. Functional, catalytic and kinetic properties: a review. J Mol Catal B 59(1-3):9-21

14. Krajewska B (2009) Ureases. II. Properties and their customizing by enzyme immobilizations: a review. J Mol Catal B 59(1-3):22-40

15. Pritchard CD, O'shea TM, Siegwart DJ, Calo E, Anderson DG, Reynolds FM, Thomas JA, Slotkin JR, Woodard EJ, Langer R (2011) An injectable thiol-acrylate poly(ethylene glycol) hydrogel for sustained release of methylprednisolone sodium succinate. Biomaterials 32(2):587-597

16. Lente G, Fábián I, Bazsa G (2007) What is and what isn't a clock reaction? New J Chem 31(10):1707

17. Muzika F, Schreiber T, Schreiberová I, Bánsági L, Taylor AF (2014) A bistable switch in pH in urease-loaded alginate beads. Chem Commun 50(76):11107-11109

18. Isakova A, Novakovic K (2017) Oscillatory chemical reactions in the quest for rhythmic motion of smart materials. Eur Polymer J 95:430-439 